\title{
Influence of Sutherlandia frutescens extracts on cell numbers, morphology and gene expression in MCF-7 cells
}

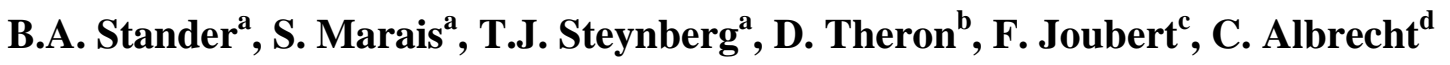 \\ and A.M. Joubert ${ }^{\mathrm{a}}$
}

${ }^{\mathrm{a}}$ Department of Physiology, University of Pretoria, P.O. Box 2034, Pretoria 0001, South Africa

${ }^{\mathrm{b}}$ ACGT Microarray Facility, University of Pretoria, 0002 Pretoria, South Africa

${ }^{c}$ Bioinformatics and Computational Biology Unit, University of Pretoria, 0002 Pretoria, South Africa

${ }^{\mathrm{d}}$ Cancer Association of South Africa, P.O. Box 2121, Bedfordview 2008, South Africa

\section{Abstract}

Sutherlandia frutescens is a well-known South African herbal remedy traditionally used for stomach problems, internal cancers, diabetes, various inflammatory conditions and recently to improve the overall health in cancer and HIV/AIDS patients. The influence of crude Sutherlandia frutescens extracts (prepared with 70\% ethanol) was investigated on cell numbers, morphology, and gene expression profiles in a MCF-7 human breast adenocarcinoma cell line. Time-dependent (24, 34, 48 and $72 \mathrm{~h})$ and dose-dependent $(0.5-2.5 \mathrm{mg} / \mathrm{ml})$ studies were conducted utilizing spectrophotometrical analysis with crystal violet as DNA stain. A statistically significant decrease to $50 \%$ of malignant cell numbers was observed after $24 \mathrm{~h}$ of exposure to $1.5 \mathrm{mg} / \mathrm{ml}$ Sutherlandia frutescens extract when compared to vehicle-treated controls. Morphological characteristics of apoptosis including cytoplasmic shrinking, membrane blebbing and apoptotic bodies were observed after $24 \mathrm{~h}$ of exposure. A preliminary global gene expression profile was 
obtained by means of microarray analysis and revealed valuable information about the molecular mechanisms and signal transduction associated with 70\% ethanolic Sutherlandia frutescens extracts.

\section{Article Outline}

1. Introduction

2. Materials and methods

2.1. Materials

2.2. Cell culture

2.3. Plant extracts preparation

2.4. Determination of cell numbers

2.5. Statistics

2.6. Cell morphology

2.7. cDNA microarray

2.8. Microarray data analysis

3. Results

3.1. Determination of cell numbers

3.2. Cell morphology

3.3. Mitotic indices

3.4. Preliminary gene expression profile in MCF-7 cells in response to Sutherlandia frutescens treatment

4. Discussion and conclusions

Acknowledgements

References

\section{Introduction}

Sutherlandia frutescens (unwele in Zulu; kankerbos in Afrikaans; cancerbush in English) is a well-known multi-purpose medicinal plant in Southern Africa and has enjoyed a long history of use by many cultures in Southern Africa as a tonic for diverse health conditions 
(Van Wyk and Gericke, 2000). Traditionally it is a popular remedy for stomach problems, internal cancers, diabetes and various inflammatory conditions (Van Wyk et al., 1997). Decoctions prepared by the Khoi and Nama people of South Africa are used externally to wash wounds and internally for fevers and as a tonic (Van Wyk and Gericke, 2000). Tai et al. (2004) revealed that ethanolic leaf extracts exhibited concentration-dependent antiproliferative activities in vitro on several human cancer cell lines including the MCF-7 cell line. Fernandes et al. (2004) described the antioxidant potential of this multi-purpose plant and concluded that Sutherlandia frutescens leaf extracts possess significant superoxide, as well as hydrogen peroxide scavenging properties. Antioxidant compounds have been shown to act on modifying immune mechanisms by modulating activity and production of cytotoxic immune cells, thus enhancing the expression of cancer suppressor genes and inhibiting tumor angiogenesis. This partly explains the anticancer effect observed in some cancers according to preliminary clinical evidence (Shklar, 1998 and Gericke et al., 2001).

In a study conducted by Tai et al. (2004), it was found that the leaves of the Sutherlandia frutescens plant contain several biological active chemicals including 1-canavanine, pinitol, gamma-aminobutyric acid, methyl and propyl parabens, saponins, as well as several chemicals with unknown effects on human physiology including sigma-4-en-3one and gamma-sitosterol. 1-Canavanine, a natural l-arginine analog and its metabolite, canaline, exert antitumor properties (Berjis and Green, 1986, Swaffar et al., 1995 and Jang et al., 2002) and are likely two of many factors contributing to the in vitro antiproliferative and apoptotic activity of Sutherlandia frutescens. Chinkwo (2005) demonstrated that Sutherlandia frutescens extracts induced apoptosis in three different cell lines (CHO, Caski and Jurkat T lymphoma cells) and it was suggested that apoptosis occurred as a result of flip-flop translocation of phosphatidyl serine.

An advantage for the use of Sutherlandia frutescens as an adaptogenic tonic includes its relative safety with the only known side effects being occasional mild diarrhea, dry mouth, mild diuresis and dizziness in cachectic patients (Mills et al., 2005). In a 3-month toxicity study of oral Sutherlandia frutescens leaf powder conducted on vervet monkeys, 
it was revealed that quantities up to nine times the recommended dose of $9 \mathrm{mg} /(\mathrm{kg}$ day $)$ were safe for consumption with no side effects (Medical Research Council and National Research Foundation of South Africa, 2002). Sutherlandia frutescens is also relatively economical to acquire. The use of traditional medicine for the treatment of various maladies in many parts of Africa is an inherent characteristic of the continent. However, the precise nature and mechanism of ethanolic extracts of Sutherlandia frutescens and its antiproliferative and apoptotic properties need to be fully investigated to support the use of traditional medicine as an alternative to often-expensive conventional medicine. It has been previously commented that the bioactivity of Sutherlandia frutescens might be as a result of synergistic effects of compounds present in Sutherlandia frutescens extracts and that the bioactivity of the extracts may not be solely dependent on a single compound, rather a host of phytocompounds resulting in a relatively complex mechanism of action (Tai et al., 2004). The aim of the study was to investigate the influence of Sutherlandia frutescens extracts at a concentration responsible for causing $50 \%$ inhibition of cell growth after $24 \mathrm{~h}$ of exposure on gene expression profiles of breast adenocarcinoma (MCF-7) cells, thus contributing to the understanding of in vitro molecular mechanisms and cell signaling events associated with Sutherlandia frutescens.

\section{Materials and methods}

\subsection{Materials}

Dulbecco's minimum essential medium eagle (DMEM) with Glutamax ${ }^{\mathrm{TM}}$ (Gibco BRL, USA), Trypsin-EDTA, crystal violet, heat inactivated fetal calf serum (FCS), penicillin, streptomycin and fungizone were supplied by Highveld Biological (Pty) Ltd.

(Sandringham, South Africa). Sterile cell culture flasks and 96-well plates were obtained from Lasec (Pty) Ltd. (Honeydew, South Africa). All other chemicals were of analytical grade and supplied by Sigma Chemical Co. (St. Louis, MO, USA).

\subsection{Cell culture}

MCF-7 human breast adenoma carcinoma cell line (Highveld Biological (Pty) Ltd., Sandringham, South Africa) were cultured in DMEM and supplemented with 10\% FCS, 
$100 \mathrm{U} / \mathrm{ml}$ penicillin $\mathrm{G}, 100 \mu \mathrm{g} / \mathrm{ml}$ streptomycin and fungizone $(250 \mu \mathrm{g} / \mathrm{l})$. Cultures were maintained at $37^{\circ} \mathrm{C}$ in a humidified atmosphere containing $5 \% \mathrm{CO}_{2}$.

\subsection{Plant extracts preparation}

Specimens of Sutherlandia frutescens (family: Fabaceae) were harvested and air-dried in the shade in the vicinity of Murraysburg in the Karoo, South Africa by W. Grobler. The plants were identified as Sutherlandia frutescens (L.) R.Br. Var. microphylla (Burch. Ex DC) Harv., by Van Wyk of the Botany and Biotechnology Department of the University of Johannesburg (voucher specimen from W. Grobler: C. Albrecht s.n. sub. Van Wyk 4126 JRAU). The leaves and small twigs were ground to obtain a fine powder. One gram of Sutherlandia frutescens was weighed, autoclaved and mixed with $10 \mathrm{ml} \mathrm{70 \%} \mathrm{ethanol}$ to obtain a stock solution concentration of $100 \mathrm{mg} / \mathrm{ml}$ and extracted for $24 \mathrm{~h}$ at room temperature. After extraction, the supernatant was transferred to a $50 \mathrm{ml}$ tube and centrifuged at $3000 \mathrm{rpm}$ for $5 \mathrm{~min}$ to further remove any debris. The supernatant was filtered twice with a $0.22 \mu \mathrm{m}$ filter to obtain a purified $100 \mathrm{mg} / \mathrm{ml}$ stock solution.

\subsection{Determination of cell numbers}

Five thousand MCF-7 cells were seeded per well in 96-well plates. Cells were cultured for $24 \mathrm{~h}$ to allow for attachment. After growth medium had been replaced, cells were exposed to Sutherlandia frutescens concentrations ranging from 0.5 to $2.5 \mathrm{mg} / \mathrm{ml}$, as well as vehicle controls, respectively for $72 \mathrm{~h}$ in order to determine the Sutherlandia frutescens concentration responsible for causing 50\% inhibition of cell growth $\left(\mathrm{IC}_{50}\right)$. Subsequently a time-dependent study with intervals of $24,36,48$ and $72 \mathrm{~h}$ were conducted with the $\mathrm{IC}_{50}$ concentration and vehicle-treated control, respectively. Cell numbers were determined spectrophotometrically with crystal violet as a DNA stain (Joubert et al., 2003).

\subsection{Statistics}

Data obtained from independent experiments are shown as the mean \pm S.D. and were statistically analyzed for significance using the analysis of variance-single factor model followed by a two-tailed Student's $t$-test. Means are presented in bar charts, with T-bars 
referring to standard deviations. $P$-values $<0.05$ were regarded as statistically significant and indicated by an * or number as indicated in the legends.

\subsection{Cell morphology}

Two hundred and fifty thousand MCF-7 cells were seeded onto heat-sterilized coverslips in six-well plates and allowed to attach as described above and subsequently exposed to $1.5 \mathrm{mg} / \mathrm{ml}$ of Sutherlandia frutescens extract for periods of $24,36,48$ and $72 \mathrm{~h}$ at $37{ }^{\circ} \mathrm{C}$. Cells were fixed in Bouin's fixative for 20 min and stained by standard haematoxylin and eosin staining procedures (Lillie, 1965). Mitotic indices of vehicle-treated cells, as well as cells exposed to Sutherlandia frutescens for $24 \mathrm{~h}$ were determined by counting 1000 cells on every coverslip and expressed as a percentage of the total cells counted. Cells were viewed and counted with an inverted Carl Zeiss Axiovert 200 MRc5 microscope (Johannesburg, South Africa).

\section{7. cDNA microarray}

Total RNA was isolated from Sutherlandia frutescens-treated and vehicle-treated control MCF-7 cells using Qiagen's RNeasy kit (Southern Cross Biotechnology (Pty) Ltd., Cape Town, South Africa) with subsequent Qiazol (Southern Cross Biotechnology (Pty), Ltd., Cape Town, South Africa) purification. The quality of isolated RNA was verified by electrophoresis using a 1.0\% agarose-formaldehyde gel. Twenty micrograms of total RNA from the Sutherlandia frutescens and vehicle-treated control were each separately annealed to oligo(deoxythymidine) and reverse transcribed in the presence of amino-allyl labeled deoxy-UTP (Amersham Biosciences, Pittsburgh, PA, USA) using Powerscript reverse transcriptase enzyme (BD Clontech Biosciences Cape Town, South Africa). The cDNA was purified utilizing Qiagen's PCR Clean-up kit (Southern Cross Biotechnology Ltd. (Pty), Cape Town, South Africa). cDNA of Sutherlandia frutescens-treated and vehicle-treated control cells were each labeled with Cy-3 (green) and Cy-5 (red) fluorescent dyes (Amersham Biosciences, Pittsburgh, PA, USA). The Cy-dye cDNA was purified utilizing the Qiagen's PCR Clean-up kit (Southern Cross Biotechnology (Pty), Ltd., Cape Town, South Africa). A hybridization mixture was prepared by adding 40 pmol of Cy-3 and Cy-5 labeled cDNA to a final volume of $28 \mu 1$. Seven microlitres of 
$10 \times$ control targets was added together with $35 \mu 12 \times$ hybridization buffer to provide a final volume of $70 \mu \mathrm{l}$. This mixture was pipetted onto Agilent's $22 \mathrm{k} 60$-mer human oligonucleotide slide (Agilent Technologies (Pty), Ltd., Palo Alto, CA, USA) and propagated over the whole slide as a result of capillary action of the liquid and coverslip. The slides were sealed in an incubation chamber and incubated for $14 \mathrm{~h}$ at $42{ }^{\circ} \mathrm{C}$. Subsequently the slides were washed twice in Falcon tubes containing $6 \times$ sodium citrate buffer (SSC), 0.005\% Triton X-100 and washed once for $10 \mathrm{~min}$ in a Falcon tube containing $0.1 \times \mathrm{SSC}, 0.005 \%$ Triton $\mathrm{X}-100$ at $4{ }^{\circ} \mathrm{C}$. Slides were scanned with the Axon Genepix 4000B Scanner (Molecular Devices Corporation, Sunnyvale, CA, USA)

provided by the African Centre of Gene Technology (ACGT) Microarray Facility (University of Pretoria, Pretoria, South Africa).

\subsection{Microarray data analysis}

Spotfinding was performed using Genepix (Molecular Devices Corporation, Sunnyvale, CA, USA). Background correction, filtering and normalization were performed using the Linear Models for Microarray Data (LIMMA) module in Bioconductor. Background subtraction was used and spots flagged as problematic in Genepix were zero-weighted. Global Loess normalization was performed within arrays. Least-squares fitting was used for the linear model calculation. Mapping of genes to metabolic pathways and Gene Ontology (GO) categories was performed using FATIGO.

\section{Results}

\subsection{Determination of cell numbers}

The antiproliferative effects of ethanolic plant extracts from Sutherlandia frutescens were determined by crystal violet DNA staining assays. The dosage of the ethanol plant extract required to statistically significantly inhibit $50 \%$ of $\mathrm{MCF}-7$ cell-proliferation $\left(\mathrm{IC}_{50}\right)$ after $24 \mathrm{~h}$ of exposure was found to be $1.5 \mathrm{mg} / \mathrm{ml}$ compared to the vehicle-treated control. A time-dependent study over $72 \mathrm{~h}$ with intervals of $24,36,48$ and $72 \mathrm{~h}$ was conducted with the $\mathrm{IC}_{50}$ concentration and revealed a similar pattern of 40-50\% growth inhibition over the entire period of the experiment compared to the cells propagated in growth medium (Fig. 1A-D). 

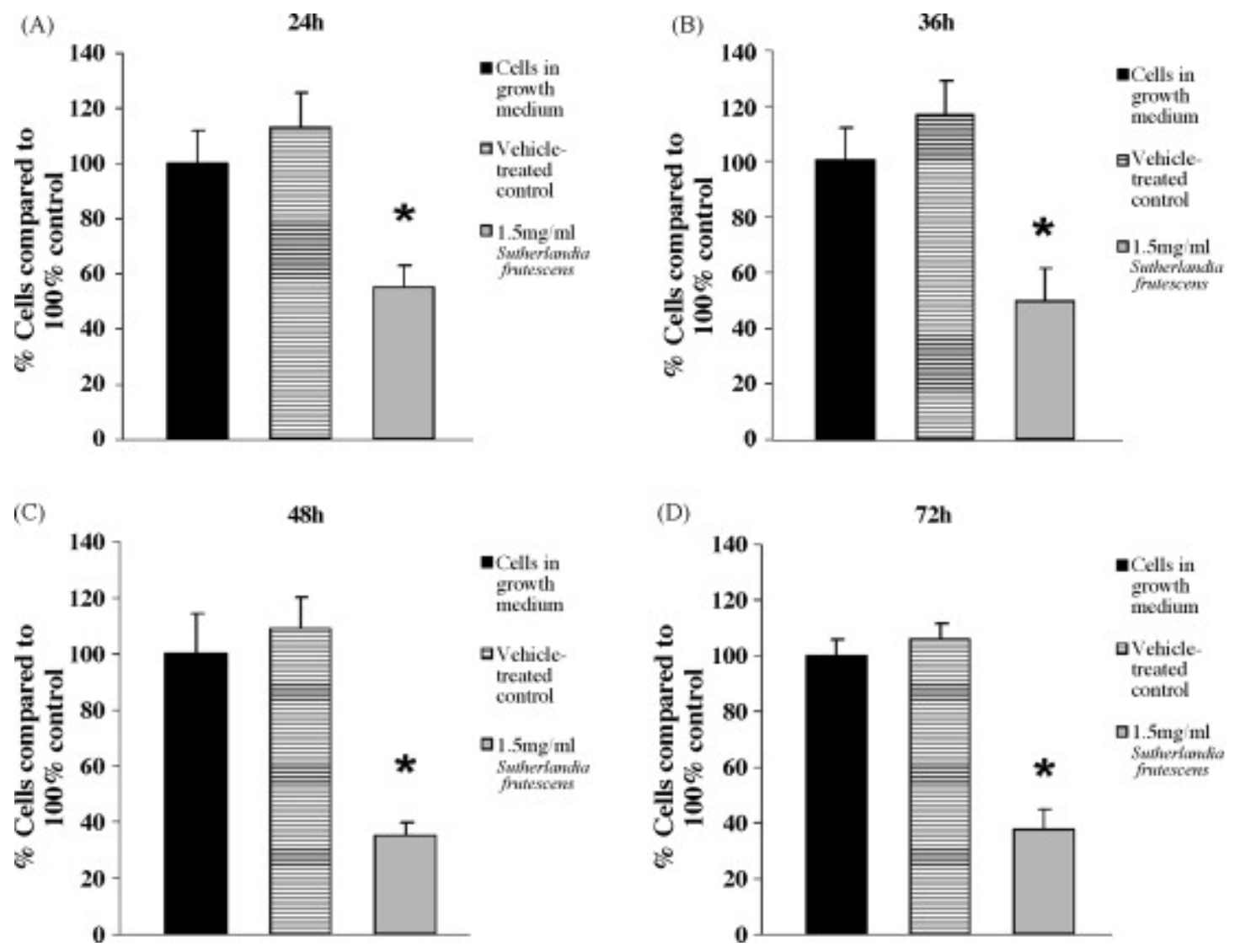

Fig. 1. Antiproliferative effects of $1.5 \mathrm{mg} / \mathrm{ml}$ Sutherlandia frutescens ethanolic extracts over periods of $24,36,48$ and $72 \mathrm{~h}$ compared to cells propagated in growth medium $(100 \%)$ and vehicle-treated controls.

\subsection{Cell morphology}

Differences in cell densities between the vehicle-treated (Fig. 2A) and Sutherlandia frutescens-treated (Fig. 2B) cells were observed after $24 \mathrm{~h}$ of exposure $(100 \times$ magnification). At a higher magnification (400×), the vehicle-treated control (Fig. 2C) exhibited a normal distribution of cells in mitosis and a majority of cells in interphase. In contrast to the vehicle-treated control, Sutherlandia frutescens-treated cells showed morphological hallmarks of apoptosis (Fig. 2D). The amount of cells revealing apoptotic characteristics was increased with prolonged exposure times of 36,48 and $72 \mathrm{~h}$ to Sutherlandia frutescens leading to a further decrease in cell density (data not shown). 
(A)

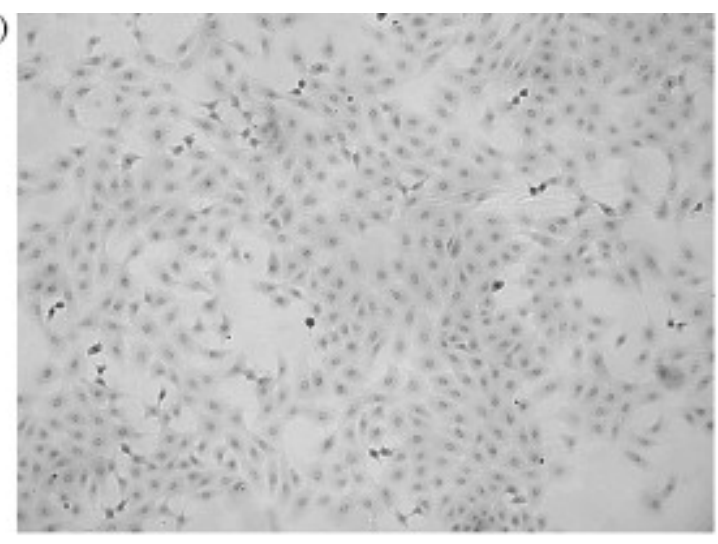

(C)

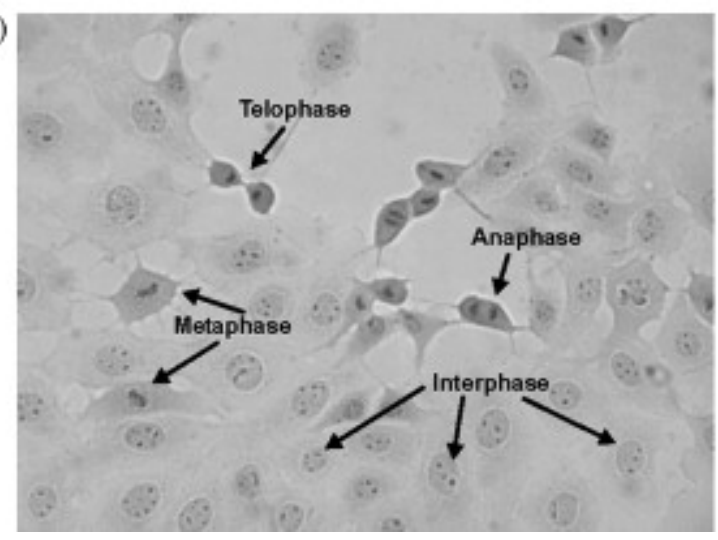

(B)

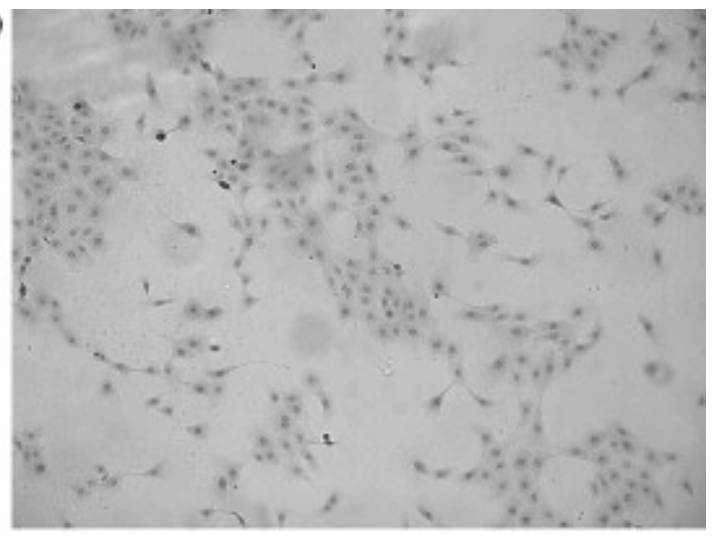

(D)

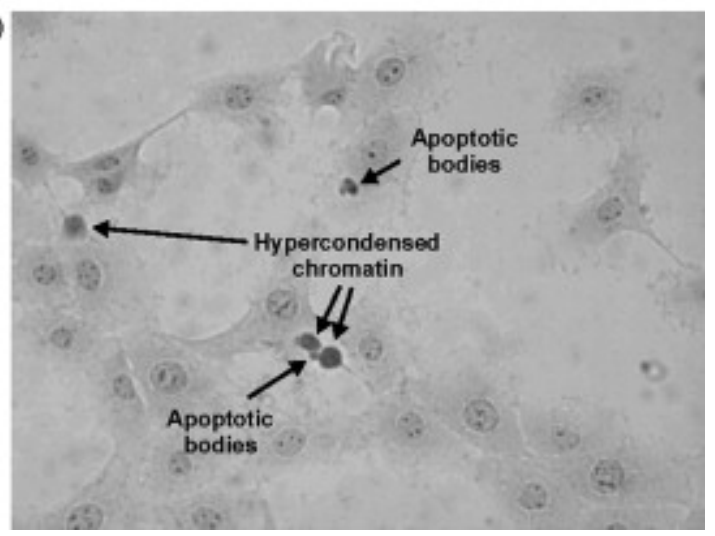

Fig. 2. Morphological analysis of vehicle-treated control (A) and $1.5 \mathrm{mg} / \mathrm{ml}$ Sutherlandia frutescens-treated (B) MCF-7 cells after $24 \mathrm{~h}$ of exposure (100× magnification).

Sutherlandia frutescens-treated cells were less dense when compared to vehicle-treated control cell populations. Vehicle-treated control cells (C) (400× magnification) showed normal cell division (metaphase, anaphase, telophase) and cells in interphase. $1.5 \mathrm{mg} / \mathrm{ml}$ Sutherlandia frutescens-treated cells (D) (400× magnification) revealed hallmarks of apoptosis including hypercondensed chromatin and formation of apoptotic bodies, with visible cell debris.

\subsection{Mitotic indices}

Mitotic indices where determined by manually counting 1000 cells after $24 \mathrm{~h}$ of treatment with Sutherlandia frutescens and vehicle, respectively. Treated cells showed a decrease in the mitotic index with $6.9 \%$ actively dividing in comparison to vehicle-treated control cells with $10.3 \%$ of the cells actively dividing. The vehicle-treated control cells exhibited an increased occurrence of cells in telophase (4.2\%) compared to Sutherlandia 
frutescens-treated cells (2.0\%). An increased occurrence of apoptosis was observed with Sutherlandia frutescens-treated cells with $3.0 \%$ of cells exhibiting morphological hallmarks of apoptosis in comparison to vehicle-treated cells exhibiting $0.5 \%$ apoptotic cells (Fig. 3). As already mentioned, the amount of cells revealing apoptotic characteristics was increased with prolonged exposure times of 36,48 and $72 \mathrm{~h}$ to Sutherlandia frutescens leading to a further decrease in cell density (data not shown).

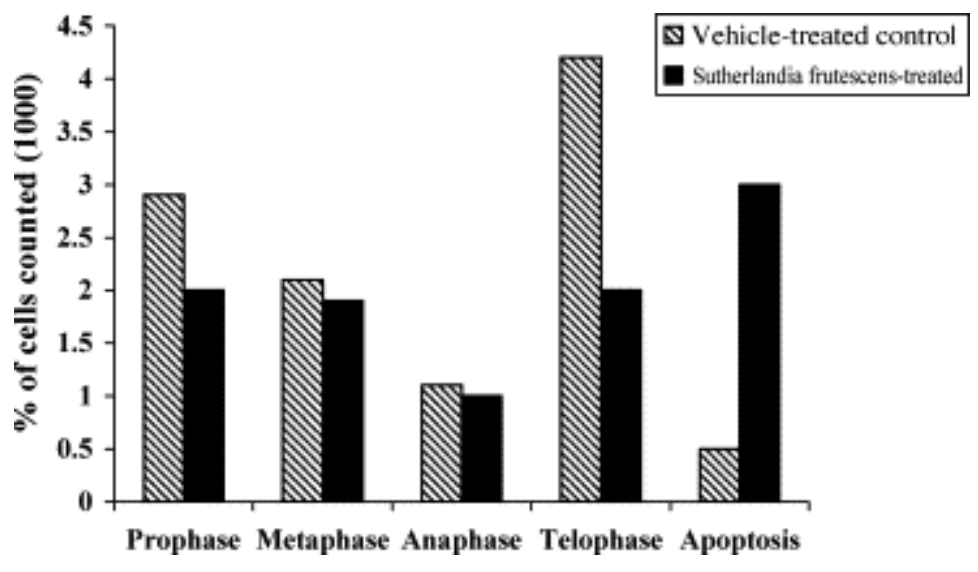

Fig. 3. Comparison of mitotic indices between Sutherlandia frutescens-treated and vehicle-treated control MCF-7 cells after $24 \mathrm{~h}$ of exposure. Results are representative from three independent experiments.

\subsection{Preliminary gene expression profile in MCF-7 cells in response to Sutherlandia frutescens treatment}

Agilent's Human 1A Oligonucleotide Microarray slides with 20173 known human 60mer oligonucleotide probes were employed to collect genomic information on the mechanism of action of Sutherlandia frutescens extracts in MCF-7 cells.

Results obtained were normalized and analyzed with the Linear Models for Microarray Data (LIMMA) analysis package (Smyth, 2005). A summary of the preliminary list of specific genes and gene clusters with a $P$-value $<0.01$ and $B$-value of $>1.2$ is represented in Table 1. In total 345 genes were statistically significantly $(P<0.01, B>1.2)$ differentially expressed (Fig. 4). The $M$-value is the mean log-expression over all the arrays in the experiment and the $B$-statistic is the log-odds of the gene that is differentially expressed (Smyth, 2005). 


\section{Table 1.}

A list of selected genes (gene names in brackets) and gene clusters of interest in MCF-7 cells responsive to ethanolic extracts of Sutherlandia frutescens revealed by cDNA microarray and bioinformatics analyses $(P$-value $<0.01$ and $B$-value of $>1.2)$

\begin{tabular}{|c|c|c|c|}
\hline Genes & $\begin{array}{l}M- \\
\text { value }\end{array}$ & $\begin{array}{l}P \text { - } \\
\text { value }\end{array}$ & $\begin{array}{l}B \text { - } \\
\text { value }\end{array}$ \\
\hline \multicolumn{4}{|l|}{ Apoptosis } \\
\hline $\begin{array}{l}\text { Tumor necrosis factor receptor superfamily, member 10a } \\
\text { (TNFRSF10A) }\end{array}$ & -1.89 & 0.0083 & 1.74 \\
\hline $\begin{array}{l}\text { Tumor necrosis factor receptor superfamily, member } 10 \mathrm{~b} \\
\text { (AF018658) }\end{array}$ & -2.64 & 0.0083 & 2.27 \\
\hline $\begin{array}{l}\text { Caspase recruitment domain family, member } 11 \\
\text { (CARD11) }\end{array}$ & -2.09 & 0.0080 & 3.59 \\
\hline \multicolumn{4}{|l|}{ Cell cycle } \\
\hline Homo sapiens retinoblastoma binding protein 5 (RBBP5) & 1.95 & 0.0084 & 2.07 \\
\hline Homo sapiens retinoblastoma binding protein 8 (RBBP8) & 2.40 & 0.0090 & 1.53 \\
\hline Akt1 substrate 1 (AKT1S1) & 2.48 & 0.0089 & 1.67 \\
\hline $\begin{array}{l}\text { V-myc myelocytomatosis viral oncogene homolog } 2 \\
\text { (MYCL2) }\end{array}$ & -1.96 & 0.0080 & 3.56 \\
\hline Kinesin family member $2 \mathrm{C}$ (KIF2C) & -1.62 & 0.0086 & 1.84 \\
\hline Kinesin family member C1 (BC000712) & -4.61 & 0.0093 & 1.42 \\
\hline \multicolumn{4}{|l|}{ Signal transduction } \\
\hline $\begin{array}{l}\text { Protein phosphatase 2A catalytic subunit, beta isoform } \\
\text { (BC012022) }\end{array}$ & 1.90 & 0.0083 & 3.01 \\
\hline Protein tyrosine phosphatase, receptor type, F (PTPRF) & 1.52 & 0.0098 & 1.26 \\
\hline
\end{tabular}




\begin{tabular}{|l|l|l|l|}
\hline Genes & $\begin{array}{l}\text { M- } \\
\text { value }\end{array}$ & $\begin{array}{l}\boldsymbol{P} \text { - } \\
\text { value }\end{array}$ & $\begin{array}{l}\text { B- } \\
\text { value }\end{array}$ \\
\hline NFKB inhibitor interacting Ras-like 2 (NFKBIE) & -1.62 & 0.0091 & 1.52 \\
\hline Mitogen-activated protein kinase kinase 5 (MEK5) & -2.30 & 0.0098 & 1.23 \\
\hline Protein inhibitor of activated STAT1 (PIAS1) & -1.80 & 0.0083 & 2.46 \\
\hline & & & \\
\hline Other & 1.57 & 0.0091 & 1.49 \\
\hline Neutral sphingomyelinase-2 (SMPD3) & -1.78 & 0.0090 & 1.62 \\
\hline Metalloprotease with thrombospondin type (ADAMTS20) & -2.05 & 0.0083 & 2.78 \\
\hline Matrix metalloproteinase 16 (MMP16) & -2.24 & 0.0080 & 3.40 \\
\hline Matrix metalloproteinase 21 (MMP21) & & & \\
\hline
\end{tabular}

$M$-values represent the log-ratio of the expression intensities. $B$-values are the log-odds of the genes that are differentially expressed. Increased $B$-values indicates that a gene is more likely to be differentially expressed.

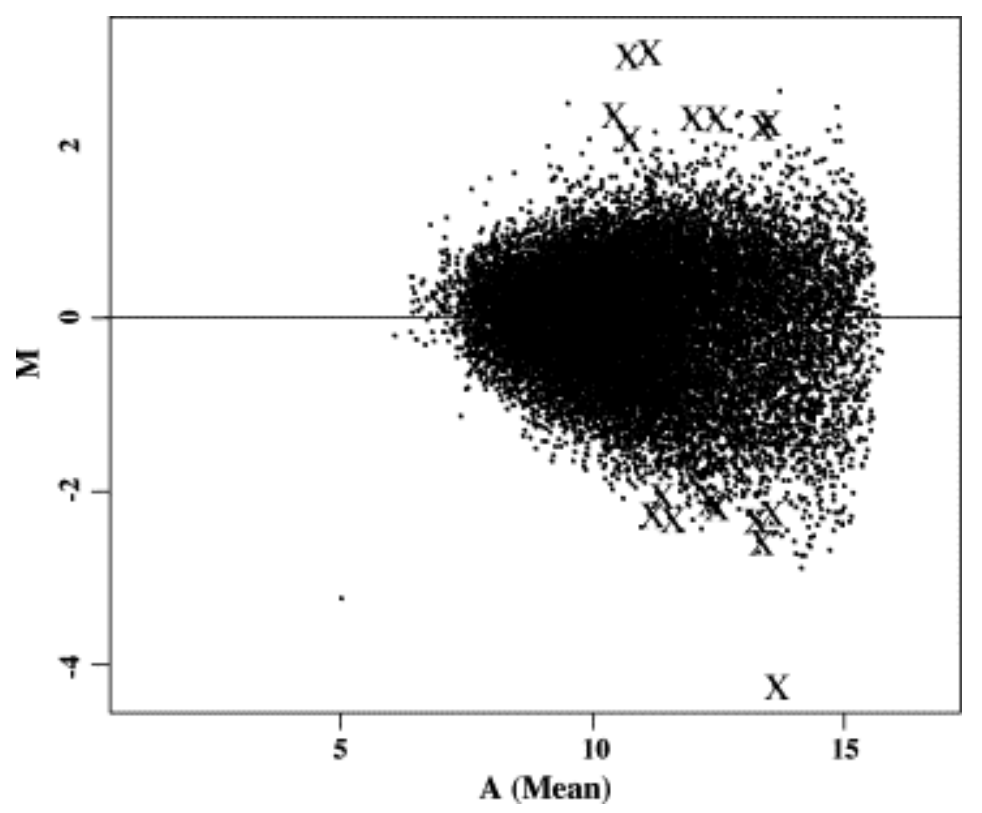


Fig. 4. MA plot of normalized data of (Treated)-(Control) with the top 20 differentially expressed genes indicated. $M$-values represent the log-ratio of the expression intensities and $A$-values represent the mean log-expression values.

\section{Discussion and conclusions}

In the present study we have demonstrated that ethanolic extracts of Sutherlandia frutescens inhibited proliferation of MCF-7 mammary adenocarcinoma cells over a period of $72 \mathrm{~h} .1 .5 \mathrm{mg} / \mathrm{ml}$ of the ethanol plant extract was found to statistically significantly inhibit $50 \%$ of MCF-7 cell-proliferation after $24 \mathrm{~h}$ of when compared to the vehicle-treated control. In addition, a time-dependent study over $72 \mathrm{~h}$ with intervals of $24,36,48$ and $72 \mathrm{~h}$ conducted with $1.5 \mathrm{mg} / \mathrm{ml}$ Sutherlandia frutescens extracts revealed a similar pattern of $40-50 \%$ growth inhibition over the entire period of the experiment compared to the cells propagated in growth medium. Morphological analysis of Sutherlandia frutescens-treated cells demonstrated an increase in apoptotic cells compared to the vehicle-treated control, suggesting that apoptosis might play a role in the growth inhibitory effects of Sutherlandia frutescens-treated MCF-7 cells. It is interesting to note that throughout the time-dependent growth study, the vehicle-treated control cells exhibited increased growth compared to MCF-7 cells propagated in growth medium. An increase in the number of cells in telophase was observed in the vehicle-treated control. This can partly be explained by the mitogen-activated protein kinase potentiation (MAPK) of ethanol on MCF-7 cells observed by Izevbigie et al. (2002). However, it is proposed that the Sutherlandia frutescens extract negated the MAPK stimulatory effects of ethanol, leading to a decrease in the amount of cells in mitosis. The mitogen-activated protein kinase pathway, MEK5-BMK1/ERK5, has been implicated as a central mediator in survival signaling and apoptotic regulation in MCF-7 cells (Weldon et al., 2002). Downregulation of the MEK5 gene as a result of Sutherlandia frutescens treatment might result in the attenuation of the MEK5-BMK1/ERK5 pathway and thereby influence cell growth negatively.

The preliminary gene expression profile provides a valuable insight into the possible mechanisms involved in the antiproliferative effects of Sutherlandia frutescens. Of 
particular interest amongst the differentially expressed genes are the Tumor necrosis factor receptor superfamily member 10a and b (DR4, DR5), CARMA1, Protein inhibitor of activated STAT1 (PIAS1), V-myc myelocytomatosis viral oncogene homolog 2, NFKB inhibitor interacting Ras-like 2, AKT1 substrate 1 and Neutral sphingomyelinase2; all of which have been reported to play important roles in apoptosis, growth inhibition and NF-кB signaling (Stephanou and Latchman, 2003, Marchesini et al., 2004, Wajant, 2004, Cheng et al., 2005, Liu et al., 2005 and Robinson et al., 2006). Signal transducer and activator of transcription 1 (STAT-1) regulates apoptosis by inducing pro-apoptotic regulatory genes, as well as inhibiting NF- $\kappa$ B activation (Battle and Frank, 2002). STAT1 enhances p53 stability by inhibiting the MDM2 gene, the major factor that controls p53 proteasomal degradation and also associates with p53 to enhance p53-mediated gene activity and apoptosis (Stephanou and Latchman, 2003). PIAS1 protein interacts with STAT-1 to suppress its DNA-binding activity (Greenhalgh and Hilton, 2001). Expression of the PIAS1 gene was found to be downregulated in Sutherlandia frutescens-treated cells compared to the vehicle-treated control. The effects of decreased intracellular levels of PIAS1 proteins on STAT-1 activity in MCF-7 cells provide a possible mechanism for induction of apoptosis.

Research has shown (Chinkwo, 2005) that Sutherlandia frutescens extracts induced DNA fragmentation in a similar fashion to known inducers such as ceramide. Ceramide is a major sphingolipid metabolite and has been demonstrated to play an important role in cell cycle arrest and apoptosis. Ceramide mediates its effect by activating several kinases and phophatases involved in stress-signaling cascades (Pettus et al., 2002 and Ruvolo, 2003). The ability of ceramide to activate protein phophatases such as protein phosphatase 1 (PP1) and protein phosphatase 2A (PP2A) can cause it to indirectly inhibit key components of pro-growth signaling such as protein kinase B/Akt and activated retinomablastoma proteins $(\mathrm{Rb})$ (Ruvolo, 2003). Intracellular generation of ceramide is derived from sphingomyelinase (SMase)-mediated hydrolysis of sphingomyelin. Sphingomyelinases are rapidly activated by diverse stress stimuli and results in increased intracellular ceramide levels (Reynolds et al., 2004). The neutral sphingomyelinase-2 (SMPD3) gene was found to be upregulated in Sutherlandia frutescens-treated cells 
compared to vehicle-treated control cells. MCF-7 cells overexpressing neutral sphingomyelinase-2 (nS-Mase-2) had increased endogenous ceramide levels and exhibited a significant decrease in growth (Marchesini et al., 2004). In addition, ceramide has the ability to induce downregulation of the proto-oncogene, c-myc (Wolff and Dobrowsky, 1994) and from the microarray data it can be seen that the MYC2L gene expression was downregulated. This study therefore suggests that the formation of ceramide might play a central role in the growth inhibitory effects of Sutherlandia frutescens extracts on MCF-7 cells.

Other interesting findings in the expression data revealed the downregulation of several metalloproteinases (MMP) including MMP-16 and MMP-21. MMPs are a family of zinc endopeptidases capable of digesting various extracellular matrix components. MMPs control cell migration, proliferation and apoptosis and regulate tumor expansion, angiogenesis and dissemination (Sounni and Noel, 2005). The role of downregulated MMPs as a result of Sutherlandia frutescens and the effect on cell growth on MCF-7 cells in vitro is unclear and remains to be investigated.

To facilitate Sutherlandia's effectiveness in vivo, the active substances must be absorbed and presented to the targets at concentrations that can exert an effect. However, little is known regarding the pharmacokinetics of compounds contained in Sutherlandia frutescens extracts, complicating correlation between in vitro and in vivo results. Future research involving the pharmacokinetics of alleged bioactive principles following the ingestion of Sutherlandia is crucial to permit accurate interpretation of in vitro data and for the development of suitable in vivo experiments (Tai et al., 2004).

The present investigation is a novel and first research study where microarray and bioinformatics were applied for the simultaneous analysis of transcription levels of 20173 oligonucleotide probes that represent molecules in the human genome across the transcripts of full length annotated genes. Our results have demonstrated that $70 \%$ ethanolic extracts of Sutherlandia frutescens inhibited cell growth and induced morphological hallmarks of apoptosis in MCF-7 cells. In addition, the preliminary global 
gene expression profiles revealed target molecules influenced by these extracts, thus contributing to the unraveling of the in vitro molecular mechanisms and signal transduction associated with $70 \%$ ethanolic Sutherlandia frutescens extracts, providing a basis for further research on this multi-purpose medicinal plant in Southern Africa.

\section{References}

Battle and Frank, 2002 T.E. Battle and D.A. Frank, The role of STATs in apoptosis, Current Molecular Medicine 4 (2002), pp. 381-392.

Berjis and Green, 1986 M. Berjis and M.H. Green, Selective cytotoxicity of l-canavanine in tumorigenic. Madin-Darby canine kidney T1 cells, Chemico-Biological Interactions 3 (1986), pp. 305-315.

Cheng et al., 2005 J.Q. Cheng, C.W. Lindsley, G.Z. Cheng, H. Yang and S.V. Nicosia, The Akt/PKB pathway: molecular target for cancer drug discovery, Oncogene 50 (2005), pp. 7482-7492.

Chinkwo, 2005 K.A. Chinkwo, Sutherlandia frutescens extracts can induce apoptosis in cultured carcinoma cells, Journal of Ethnopharmacology 98 (2005), pp. 163-170.

Fernandes et al., 2004 A.C. Fernandes, A.D. Cromarty, C. Albrecht and C.E. Van Rensburg, The antioxidant potential of Sutherlandia frutescens, Journal of Ethnopharmacology 95 (2004), pp. 1-5.

Gericke et al., 2001 N. Gericke, C.F. Albrecht, B. Van Wyk, B. Mayeng, C. Mutwa and A. Hutchings, Sutherlandia frutescens, Australian Journal of Medical Herbalism 13 (2001), pp. 9-15.

Greenhalgh and Hilton, 2001 C.J. Greenhalgh and D.J. Hilton, Negative regulation of cytokine signaling, Journal of Leukocyte Biology 3 (2001), pp. 256-348.

Izevbigie et al., 2002 E.B. Izevbigie, S.I. Ekunwe, J. Jordan and C.B. Howard, Ethanol modulates the growth of human breast cancer cells in vitro, Experimental Biology and Medicine 4 (2002), pp. 260-265.

Jang et al., 2002 M.H. Jang, Y. Jun do, S.W. Rue, K. Han, W. Park and Y.H. Kim, Arginine antimetabolite 1-canavanine induces apoptotic cell death in human Jurkat T cells 
via caspase-3 activation regulated by Bcl-2 or Bcl-xL, Biochemical and Biophysical Research Communications 295 (2002), pp. 283-288.

Joubert et al., 2003 A.M. Joubert, A. Panzer, P.C. Bianchi and M.L. Lottering, The effects of prostaglandin A2 on cell growth, cell cycle status and apoptosis induction in HeLa and MCF-7 cells, Cancer Letters 2 (2003), pp. 203-209.

Lillie, 1965 R.D. Lillie, Histopathologic Technic and Practical Histochemistry, McGrawHill Book Co., New York (1965) p. 445.

Liu et al., 2005 B. Liu, R. Yang, K.A. Wong, C. Getman, N. Stein, M.A. Teitell, G. Cheng, $\mathrm{H}$. Wu and K. Shuai, Negative regulation of NF-kappaB signaling by PIAS1, Molecular and Cellular Biology 3 (2005), pp. 1113-1123.

Marchesini et al., 2004 N. Marchesini, W. Osta, J. Bielawski, C. Luberto, L.M. Obeid and Y.A. Hannun, Role for mammalian neutral sphingomyelinase 2 in confluenceinduced growth arrest of MCF7 cells, Journal of Biological Chemistry 24 (2004), pp. 25101-25111.

MRC and NRFSA, 2002 Medical Research Council and National Research Foundation of South Africa, 2002. A toxicity study of Sutherlandia leaf powder (Sutherlandia microphylla) consumption. Final Report 2002.

Mills et al., 2005 E. Mills, C. Cooper, D. Seely and I. Kanfer, African herbal medicines in the treatment of HIV: Hypoxis and Sutherlandia. An overview of evidence and pharmacology, Nutrition Journal 4 (2005), pp. 1-6.

Pettus et al., 2002 B.J. Pettus, C.E. Chalfant and Y.A. Hannun, Ceramide in apoptosis: an overview and current perspectives, Biochimica et Biophysica Acta 2 (2002), pp. 114-125. Reynolds et al., 2004 C.P. Reynolds, B.J. Maurer and R.N. Kolesnick, Ceramide synthesis and metabolism as a target for cancer therapy, Cancer Letters 2 (2004), pp. 169-180.

Robinson et al., 2006 K. Robinson, L. Vona-Davis, D. Riggs, B. Jackson and D. McFadden, Peptide YY attenuates STAT1 and STAT3 activation induced by TNF-alpha in acinar cell line AR42J, Journal of the American College of Surgery 5 (2006), pp. 788796.

Ruvolo, 2003 P.P. Ruvolo, Intracellular signal transduction pathways activated by ceramide and its metabolites, Pharmacological Research 5 (2003), pp. 383-392. 
Shklar, 1998 G. Shklar, Mechanism of cancer inhibition by anti-oxidant nutrients, Oral Oncology 34 (1998), pp. 24-29.

Smyth, 2005 G.K. Smyth In: R. Gentleman, V. Carey, S. Dudoit, R. Irizarry and W. Huber, Editors, Limma: Linear Models for Microarray Data. Bioinformatics and Computational Biology Solutions using R and Bioconductor, Springer, New York (2005), pp. 397-420.

Sounni and Noel, 2005 N.E. Sounni and A. Noel, Membrane type-matrix metalloproteinases and tumor progression, Biochimie 3 (2005), pp. 329-342.

Stephanou and Latchman, 2003 A. Stephanou and D.S. Latchman, STAT-1: a novel regulator of apoptosis, International Journal of Experimental Pathology 6 (2003), pp. 239-244.

Swaffar et al., 1995 D.S. Swaffar, C.Y. Ang, P.B. Desai, G.A. Rosenthal, D.A. Thomas, P.A. Crooks and W.J. John, Combination therapy with 5-fluorouracil and 1-canavanine: in vitro and in vivo studies, Anticancer Drugs 4 (1995), pp. 586-593.

Tai et al., 2004 J. Tai, S. Cheung and D. Hasman, In vitro culture studies of Sutherlandia frutescens on human tumor cell lines, Journal of Ethnopharmacology 1 (2004), pp. 9-19. Van Wyk and Gericke, 2000 B.E. Van Wyk and N. Gericke, People's Plants: A Guide to Useful Plants of Southern Africa, Briza Publications, Pretoria (2000).

Van Wyk et al., 1997 B.E. Van Wyk, B. Van Oudtshoorn and N. Gericke, Medicinal Plants of South Africa, Briza Publications, Pretoria (1997).

Wajant, 2004 H. Wajant, TRAIL and NFkB signaling, a complex relationship, Vitamins and Hormones 67 (2004), pp. 101-132.

Weldon et al., 2002 C.B. Weldon, A.B. Scandurro and K.W. Rolfe, Identification of mitogen-activated protein kinase kinase as a chemoresistant pathway in MCF-7 cells by using gene expression microarray, Surgery 2 (2002), pp. 293-301.

Wolff and Dobrowsky, 1994 R.A. Wolff and R.T. Dobrowsky, Role of ceramideactivated protein phosphatase in ceramide-mediated signal transduction, Journal of Biological Chemistry 30 (1994), pp. 19605-19609. 